\title{
Tourists' Satisfaction with a Destination: An Investigation on Visitors to Langkawi Island
}

\author{
Nor Khasimah Aliman ${ }^{1}$, Shareena Mohamed Hashim², Siti Dalela Mohd Wahid ${ }^{3} \&$ Syahmi Harudin $^{4}$ \\ ${ }^{1}$ Faculty of Business Management, Universiti Teknologi MARA, Seri Iskandar Campus, Malaysia \\ ${ }^{2}$ Academy of Language Studies, Universiti Teknologi MARA, Seri Iskandar Campus, Malaysia \\ ${ }^{3}$ Faculty of Business Management, Universiti Teknologi MARA, Lendu Campus, Malaysia \\ ${ }^{4}$ Faculty of Business Management, Universiti Teknologi MARA, Merbuk Campus, Malaysia \\ Correspondence: Nor Khasimah Aliman, Faculty of Business Management, Universiti Teknologi MARA, Seri \\ Iskandar Campus, Malaysia. Tel: 60-19-566-8808. E-mail: nka980@perak.uitm.edu.my
}

Received: April 5, 2016 Accepted: May 17, 2016 Online Published: May 24, 2016

doi:10.5539/ijms.v8n3p173 URL: http://dx.doi.org/10.5539/ijms.v8n3p173

\begin{abstract}
This study attempts to investigate the antecedents of tourist satisfaction. The focus of the study is Langkawi Island, a well-known tourist destination in Malaysia. Questionnaires were distributed to 500 tourists in Langkawi Island. Descriptive statistic, factor analysis and multiple regressions were run on the 482 useable data. The results indicate that $295(61.2 \%)$ of the respondents were repeat visitors and the remaining $187(38.8 \%)$ were first-timers. More than half (56.8\%) of the respondents had high levels of satisfaction with the mean items score of 3.90 and above. When factor analysis was run, seven factors emerged from the 33 items used to measure the contructs. Apart from tourist expectations, perceived quality, destination image, cost and risks, and perceived value, a new variable known as social-security was identified as a predictor. Regression analysis revealed that destination image, tourist expectations, costs and risks, and social-security have positive and significant influence on tourist satisfaction. Social-security was found to be the most important predictor of tourist satisfaction, followed by tourist expectations, destination image, and costs and risks. The findings of this study could provide guidelines for tourism managers and destination operators to further develop better strategies to satisfy travellers to Langkawi.
\end{abstract}

Keywords: tourist satisfaction, antecedents, Langkawi Island, Malaysia

\section{Introduction}

Travel and Tourism is one of the world's largest and most dynamic service industries comprising a number of different sectors including travel, hospitality and visitor services. Tourism has been selected as the focal service industry in this study because it is one of the fastest growing global industries with significant impacts across the world economies (WTO, 1995). Realizing the travel and tourism industry's role as the driver of economic growth and employment, governments all over the world have intensified efforts to compete for the tourism dollars. In fact, the World Travel and Tourism Council (2013) reported that the industry supports 225 million jobs for the skilled, semi-skilled and unskilled, and generates 9 per cent of world GDP. In the same vein, Hui et al. (2007) note that all countries develop the tourist industry because it will benefit not only the industry itself, but the other sectors as well, such as retail, transportation and construction. For the same reason, the Malaysian government has included the tourism industry as one of the 12 National Key Economic Areas (NKEAs) that will spearhead the country's transformation into a high income nation by 2020. Twelve Entry Point Projects (EPPs) across five main themes - affordable luxury; family fun; events, entertainment, spas and sports; business tourism and nature adventure - have been introduced to attract 36 million tourists and earn RM168bil in tourist receipts by 2020. According to the Performance Management Delivery Unit (2012), the EPPs are expected to provide an incremental GNI contribution of RM66.7bil and create 37,900 new job vacancies by 2020 through direct, indirect and induced employment.

\subsection{Background of the Study}

Langkawi Island is a cluster of 99 islands situated in the northern state of Kedah, on the west coast of the Peninsula of Malaysia. It is within commutable distance by ferry to Perlis and mainland Kedah and by plane to 
Kuala Lumpur. Since 1984, the Malaysian government has been actively developing and promoting Langkawi as a premier island resort equipped with modern infrastructure and facilities. Subsequently, on January 1, 1987, Langkawi was designated as a duty-free port to serve as an important catalyst to spur the socio-economic development of the island and transform its economic base from a mainly agricultural community. With its natural attributes and diverse habitats including rainforests, mangrove wetlands and coral reefs, Langkawi has the potential to offer ecotourism to nature lovers. At the same time, it is fast expanding as one of South-East Asia's premier meeting and exhibition destinations as a result of investments by both public and private sectors. The biennial Langkawi International Maritime and Aerospace Exhibition (LIMA), which was first held in 1991, continues to attract government officials, trade delegations and visitors from all parts of the world. The Langkawi Development Authority (2014) reported an increasing number of tourists over the last decade, and in 2012 alone, the island welcomed a total of 3.06 million domestic and international tourists. Although some of those tourists were first-timers, a sizeable number were repeat visitors. For the Asian and domestic visitors, duty-free shopping is an added attraction, but to the Westerners, the charm of the island lies in its natural beauty.

It is a commonly held view that tourist satisfaction is the key to the success of the tourism industry (Sadeh et al., 2012). Unfortunately, only a few academic studies have focused directly on satisfaction among tourists, and an even more limited number have been undertaken in Malaysia, specifically on Langkawi. According to Zabkar et al. (2010), studies on satisfaction in the tourist industry have always had several difficulties on conceptual and practical grounds. As such, the determinants of tourist satisfaction and the consequences need to be further explored. This research was undertaken in response to calls for more analytical insights on satisfaction of tourists visiting the island of Langkawi in Malaysia. A better understanding of the attributes that ascertain their satisfaction would be a significant step in sustaining the island's ranking as one of Malaysia's most popular holiday destinations. For this reason, the findings of this study could have a notable impact on the Langkawi Development Authority (LADA), the state government of Kedah and the policy makers in Malaysia.

\subsection{Research Objectives}

To date, no studies in tourism literature have simultaneously examined the structural relationships between tourist expectation, perceived quality, perceived value, costs and risks, and destination image as antecedents of satisfaction in Langkawi Island, Malaysia. Thus, the objectives of this study are to identify the antecedents of tourist satisfaction among visitors to the island.

\section{Literature Review}

\subsection{Tourist Satisfaction and Its Antecedents}

Severt et al. (2007) define tourist satisfaction as the extent of the tourist's fulfillment pleasure which occured from the trip experience about a product or service feature that fulfills the tourist's desires, expectations and wants in association with the trip. Satisfaction is created by the comparison of the customer's expectation before and after consumption. In tourism context, satisfaction is primarily referred to as a function of pre-travel expectations and post-travel experiences. The tourist is satisfied when experiences go beyond the expectations. However, if the tourist feels displeasure, dissatisfaction will be the expected outcome (Chen \& Chen, 2010; Reisinger \& Turner, 2003). From the foregoing discussion, it is understood that satisfaction of tourists is caused by two different dimensions: firstly, it is related to the pre-expectation of the tourist before the travel; and secondly, it is referred to the justification of the tourist on the delivered services after the travel, and based on the real experiences.

Empirical work on customer satisfaction has double managerial roles: informative and communicative (Vavra, 1997). The primary purpose of measuring and explaining customer satisfaction is to understand how well suppliers at a particular destination recognize and respond to the needs of its visitors, and to identify which elements of the destination's offer need improvement. Indeed, tourists' comments, complaints and suggestions are invaluable source of ideas for improvements and innovations. Also, tourist satisfaction research is important for successful destination marketing because it influences the choice of destination, the consumption of products and services, and the decision to return (Kozak \& Rimmington, 2000). For these reasons, satisfaction is viewed as an important research topic by both practitioners and academics (Xia et al., 2009). Yet, there is a dearth of exploratory studies aimed at providing analytical insights on satisfaction among tourists. Heung \& Qu (2000) rightly assert that the current tourism literature has mostly reported findings about tourist perceptions and satisfaction levels towards travelling in Western rather than the Asian countries.

Until recently, no mention has been made of determining the real drivers with respect to overall satisfaction with the vacation destination. Measuring tourist satisfaction with a destination is conceptually different from measuring satisfaction at the transaction specific level. Previous literature has revealed many cause-and-effect 
models for measuring customer satisfaction. However, there is no complete universal cause-and-effect model found specifically for measuring tourist satisfaction. Thus, this research incorporates the American Customer Satisfaction Index Model (ACSI), European Customer Satisfaction Index (ECSI) and other general consumer satisfaction models to generate antecedent variables of tourist satisfaction in Malaysia.

According to ACSI (Fornell et al., 1996), the three antecedents of customer satisfaction are customer expectation, perceived quality and perceived value. In the ECSI model (Eklof \& Westlund, 2002) customer expectation, perceived quality, perceived value and company image are identified as the antecedents of overall customer satisfaction. In the past decade, these models have been used widely in different geographical regions. A research conducted in Hong Kong using the same model investigated the impact of perceived attractiveness, perceived quality and perceived value on satisfaction (Um et al., 2006). Xia et al. (2009) present tourist expectation, destination image, perceived quality and perceived value as predictors of tourist satisfaction. Dmitrovic et al. (2009) suggest that quality, perceived value, image, and costs and risks are determinants of tourist satisfaction. In Western Australia, Quintal \& Polczynski (2010) studied the relationships between perceived attractiveness, perceived quality, perceived value, perceived risk and satisfaction, while in Thailand, Prayag \& Ryan (2011) investigated the role and influence of destination image, place attachment and personal involvement on visitor satisfaction. Based on this background, the present study examines five antecedents of tourist satisfaction: tourist expectation, perceived quality, perceived value, destination image, and costs and risks.

\subsection{Relationships between Variables}

\subsubsection{Tourist Expectation in Relation to Tourist Satisfaction}

Millan \& Esteban (2004) and Oliver (1997) consider expectations as important antecedents of satisfaction. Tourist expectation is an affective variable in the service sector (Sadeh et al., 2012). The study of the levels of expectation and satisfaction has paramount significance in so far as sustained development of tourism at the given destination is concerned (Lather et al., 2012). Unfortunately, researchers do not agree on how the term "tourist expectation" should be defined. Akama \& Kieti (2003) argue that tourists usually have initial expectations of a service before they consume it. Their expectations are formed through information from advertisements and word of mouth perceptions from other consumers during past experience. However, del Bosque et al. (2006) suggest that expectations are formed through past experience, the tourist's level of previous satisfaction with the service, communication from the service provider such as a promise and the tourist's perceived image of the service. According to Tribe \& Snaith (1998), expectations are what people anticipate regarding their experience. Expectations are also related to the performance of a product or service as anticipated by the consumers (Xia et al., 2009; Ngobo, 1997).

Expectations are always changing because consumers are aware of alternative service providers in the ever-growing tourism industry. A tourist's expectations directly influence his feelings about the services (satisfaction). In fact, it is a popularly held view among experts that tourist expectation directly affects perceived value and satisfaction (Song et al., 2012; Lee et al., 2011; Xia et al., 2009). The expectation of the destination can be the basis for assessment of the money paid and the service delivered (perceived value).

\subsubsection{Tourists' Perceived Quality in Relation to Tourist Satisfaction}

Another antecedent of satisfaction for this study is the perceived quality of service which is determined by customer perception. In tourism research, Chen \& Tsai (2007) define perceived quality as the "visitor's assessment of the standard of the service delivery process in association with the trip experience" (p. 1116). Among the many researchers who have undertaken studies on quality and satisfaction which relate to goods and services, a few have suggested that perceived quality and satisfaction need to be viewed as distinct constructs. This is because perceptions about quality are based on long-term cognitive evaluations of a firm's service delivery, whereas customer satisfaction is a short-term emotional reaction to a specific experience (Tian-Cole et al., 2002; Rust et al., 1999; Oliver, 1997; Taylor \& Baker, 1994). Additionally, Saleh \& Ryan (1993) state that, "Satisfaction is determined by the consumers' perceptions of the service and attention they receive from the representative of the service company with whom they are dealing" (p. 107). Thus, the researchers also pointed that perceived quality is a predictor of customer satisfaction.

Other studies have found a causal relationship between the two constructs (Spreng \& Mackoy, 1996; Cronin \& Taylor, 1992). Past studies have also suggested that perceptions of service quality and value affect satisfaction, and satisfaction then affects loyalty and post-behaviors (de Rojas \& Camarero, 2008; Chen, 2008; Chen \& Tsai, 2007; Choi \& Chu, 2001). A positive relationship between the two constructs has also been confirmed in prior investigations (Quintal \& Polczynski, 2010; Ruiz et al., 2009; de Rojas \& Camarero, 2008; Um et al., 2006; Howat \& Murray, 2002; Baker \& Crompton, 2000). Goodrich (1978) assert that, "The more favorable the 
perception of a given vacation destination, the more preferred that destination will tend to be" (p. 11). Xia et al. (2009) found a significant positive relation between perceived quality and satisfaction $(\beta=0.64, t=7.89)$, implying that visitors who perceive higher destination quality are more likely to experience greater satisfaction with the destination.

\subsubsection{Tourists' Perceived Value in Relation to Tourist Satisfaction}

Zeithaml (1988) defines perceived value as the customer's assessment of the services based on the perceptions of what is received and what is given. Rust \& Oliver (1994) adopt a microeconomic view that value is some combination of what is received (utility derived from quality) and what is sacrificed (price and other costs). Meanwhile, Lovelock (2000) views perceived value as a trade-off between perceived benefits and perceived costs. In this study, perceived value is measured by multidimensional items (Petrick \& Backman, 2002). It is viewed as a combination of both monetary and non-monetary prices including other factors such as time, search costs and convenience.

According to the Equity Theory (Oliver \& Swan, 1989), consumer satisfaction occurs when more value is received than what is spent by the consumer. Indeed, several researchers have found that when tourists perceive that the quality of services given to them is greater than the money paid by them, they will feel satisfied with the services received (Song et al., 2012; Chen \& Chen, 2010; Haung \& Su, 2010). In essence, tourist satisfaction is directly affected by perceived value-visitors who perceive higher destination value are more likely to experience greater satisfaction with the destination (Song et al., 2012; Haung \& Su, 2010; Chen \& Chen, 2010; Chen \& Tsai, 2007; Lee et al., 2007; Um et al., 2006; Deslandes, 2003). A study by Xia et al. (2009) also confirmed a significant positive relationship between perceived value and satisfaction $(\beta=0.46, t=6.23)$.

\subsubsection{Destination Image in Relation to Tourist Satisfaction}

A destination is defined as a blend of consumers' space and tourism products providing a holistic experience which is subjectively interpreted according to the consumer's travel itinerary, cultural background, purpose of visit, past experience, etc. (Fuchs \& Weiermair, 2003). According to Tasci et al., (2007) Destination image is an interactive system of thoughts, opinions, feelings, visualizations, and intentions toward destination (p. 200). Chi \& Qu (2008) define destination image as an individual's mental representation of the knowledge, feelings, and overall perception of a particular destination. It is formed as a result of interactions between cognitive, affective and conative elements (Lin et al., 2007; Gartner, 1993). Echtner \& Ritchie (1991) describe destination image as the perception of destination features or attributes known as cognitive images, while the combination of cognitive and affective images refers to mental pictures or place imagery such as a safe and enjoyable experience for the family. Similarly, Choi et al. (1999) claim that destination image is people's belief, idea or impression about a place.

Many researchers agree that destination image is important in terms of its effects on tourist behavior such as destination choice, decision making and satisfaction (Chen \& Hsu, 2000; Court \& Lupton, 1997; Schroeder, 1996; Ross, 1993). Chen, Zhang, \& Qiu (2013) pointed that the destination image is not only an important factor to the tourists' travel decision and plans, but also to the tourist satisfaction. In the English Historic Towns Forum (1992), it was found that more than $80 \%$ of visitors considered the retailing mix and general environment of the town as the most important attraction of the destination. The following factors were deemed important by tourism and leisure shoppers:

- The cleanliness of the town

- Pedestrian areas/pavements that are well maintained

- Natural features such as rivers and parks

- The architecture and facades/shop fronts

- Street furniture (seating and floral displays)

- Town center activities (e.g., outdoor markets and live entertainment)

A few destination image studies have investigated destination image as an independent variable influencing several consumer behaviour variables concerning not only before, but also during and after visiting a destination (Chen \& Hsu, 2000; Schroeder, 1996; Ross, 1993). A tourist may form a positive or negative image towards a destination. Chen \& Kerstetter (1999) claimed that tourists will choose one destination over another only when its positive image aspects exceed its negative image aspects. However, some researchers state that destination image must not only be positive but also strong to be chosen by travellers (Ross, 1993; Hunt, 1975). To measure image perceptions, the majority of studies have relied on lists of attributed measures using the scaling method 
(Prayag, 2009; Tasci \& Gartner, 2007).

Destination image may directly or indirectly affect satisfaction through tourist expectation, perceived quality and perceive value. The positive relationship between destination image and satisfaction is well established in the tourism literature for different types of destinations, including island destinations (Prayag, 2009; Xia et al., 2009; Chi \& Qu, 2008; Cheng \& Tsai, 2007; Lee et al., 2005; Bigne et al., 2001; Kozak \& Rimmington, 2000). Echtner \& Ritchie (1991) note that image is a key factor in destination choice for the first-timers. In their studies, Leong et al. (2010) and Mohamad et al. (2012) found that destination image is the antecedent to tourist satisfaction for Malaysia, and according to Mohamad et al. (2011), the country is perceived as offering natural scenic beauty supported by good facilities for food and accommodation. Similarly, research in Thailand by Nikorn \& Ampasri (2012) confirm that tourist satisfaction is positively influenced by destination image $(\lambda=0.62, t=5.75)$. Chen $\&$ Tsai (2007) also reported a positive relationship between destination image and trip quality.

\subsubsection{Costs and Risks in Relation to Tourist Satisfaction}

Any tourist will consider both costs and risks before travelling. Costs and risks may be high or low in the eyes of different individual tourists. The low risk associated with a holiday destination can influence repeat visitations, contributing to increased employment and modern infrastructure (Aqueveque, 2006; Darnell \& Johnson, 2001). Moreover, the low risk that tourists perceive in a holiday destination can impact on its reputation for safety and encourage repeat visitation (Kozak et al., 2007). Perceived costs and risks are influenced by many factors: experience, personal characteristics, environmental forces such as political stability, economic conditions, etc. As such, rational travellers normally choose to travel to destinations that offer low costs and low risks.

In the service setting, costs and risks is a different construct from perceived value (Cronin et al., 2000). Pisnik \& Snoj (2007) consider costs and risks as an independent variable that causes disutility. Monroe (1990) and Zeithaml (1988) propose costs and risks as a sacrifice construct which includes the element of price and non-price components (e.g., the time and effort invested in pre-purchase activities). The risks associated with the purchase may also include social desirability and security. Tasci \& Boylu (2010) indicated that safety and security of a destination are seen to have a big impact on the level of satisfaction with a tourist trip.

Previous studies have observed the negative effect of perceived risk on satisfaction (Fornell et al., 2006; Yuksel \& Yuksel, 2007). Both Monroe (1990) and Zeithaml (1988) indicate that costs and risks are negatively related to perceived value and it can adversely affect customer satisfaction. Therefore, visitors who perceive lower risk are more likely to experience greater satisfaction with the destination.

\section{Methodology}

A survey using close-ended questions was used to gather data on the predictors and criterion variable, as well as on specific demographic characteristics.

\subsection{Research Framework and Measures}

Based on past studies, a blend of five variables was considered to have influence on tourist satisfaction with Langkawi Island. Twenty-four items were used to measure the predictor variables. In this research, expectation is measured using three dimensions: overall expectations of quality, expectations regarding customization, and expectations regarding reliability (Fornell et al., 1996). To assess perceived quality, the present research uses seven items adopted from Xia et al. (2009), Hui et al. (2007), Chen \& Tsai (2007) and Wang et al. (2005). Perceived value has been measured using three dimensions (price, time and effort). These dimensions were employed by Xia et al. (2009), Chen \& Tsai (2007), Bolton \& Drew (1991), and Oliver \& Swan (1989) in their investigations. Destination image in this study is measured using the six components of tourism destination proposed by Buhalis (2000) which include attractions, amenities, accessibility, activities, ancillary services, and available packages. Finally, costs and risks construct was measured using five (5) items - price, time, effort, social desirability and security. The criterion variable, tourist satisfaction was measured using nine (9) items modified from Dmitrovic et al. (2009), Oliver (1980), Taylor \& Baker (1994), Grace \& O'Cass (2005) and Wu et al. (2008). The research framework is shown schematically in Figure 1.

A five-point Likert-type scale, ranging from (1) strongly disagree to (5) strongly agree was used to measure the independent and dependent variables. Demographic variables were measured using nominal and ordinal scales. 


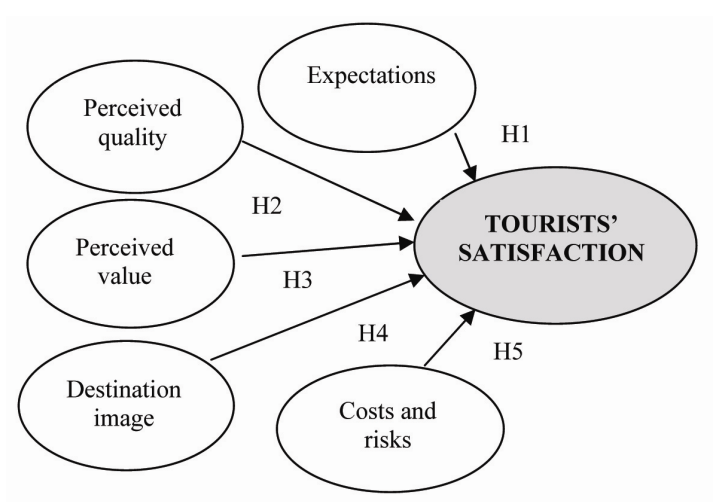

Figure 1. Proposed research framework

\subsection{Research Hypotheses}

Based on the proposed research framework, the researchers developed the following five hypotheses:

H1: Tourist expectations for a destination have a positive effect on tourist satisfaction.

H2: Perceived quality has a positive effect on tourist satisfaction

H3: Perceived value has a positive effect on tourist satisfaction

H4: The more positive the destination images are, the higher the satisfaction levels.

H5: Costs and risks directly influence tourist satisfaction.

\subsection{Pilot Test}

Prior to the data collection, the questionnaires were pilot tested on 50 respondents in September of 2012. Similar tests were also carried out by Hui et al. (2007) in Singapore, and by Prayag \& Ryan (2012) in Mauritius. The result of the pilot test indicated that most of the items used to measure the variables had a mean score of more than 3.0, which was more than the average score of the five-point Likert scale. The reliability score for the predictors and criterion variables were above 0.50 and considered acceptable for basic research by Nunnally (1978) (Refer to Appendix A).

\subsection{Target Population, Sample and Data Collection}

In 2012, about 3.06 million tourists visited Langkawi Island. Based on the target population of 2012, the targeted sample size for this study was determined. As suggested by Roscoe (1975), a sample of more than 30 and less than 500 is sufficient for most research. Thus, 500 survey questionnaires were distributed to the visitors at various tourist spots such as the Langkawi Ferry Terminal, Airport and Cenang Beach in March and May of 2013. This sample size is consistent with similar research conducted in other countries. For instance, Chanin (2011) used 251 international tourists in Thailand, Chen \& Chen (2010) surveyed 477 tourists in Tainan, Taiwan, Hui et al. (2007) investigated 424 tourists in Singapore, while Joppe et al. (2001) surveyed 359 tourists in Toronto. Since the visitors were preoccupied with their holiday activities, convenience sampling was employed to select the respondents.

\subsection{Data Analysis}

Both descriptive and inferential statistics were used to analyze the data. Demographic variables were reported using frequency counts. Every item used to measure the variables was analyzed using mean score and standard deviation. Conformatory factor analysis was carried out to identify the number of factors that emerged. Cronbach's Alpha was calculated to test the internal consistency of the items, and hypotheses testing were conducted using multiple regressions.

\section{Research Results}

\subsection{Respondents Profile}

The research respondents comprised tourists from Malaysia and other countries such as Indonesia, Thailand, Canada, Iran and so on. Out of the 482 respondents, 426 (88.4\%) were Malaysian citizens while $56(11.6 \%)$ were non-citizens. The subjects were categorized into two groups: first-time visitors $(187 / 38.8 \%)$ and repeat visitors $(295 / 61.2 \%)$. There were 261(54.1\%) female respondents and $221(45.9 \%)$ male respondents. About $70 \%$ of the 
respondents were Malay Bumiputra, and the remaining were Chinese, Indians and foreign nationals. The respondents represented various age groups but the majority (74.3\%) was aged between 21 to 49 years old. Half $(50 \%)$ of the respondents were single, while married couples made up $47.3 \%$ of the sample. One hundred and thirty-two (27.4\%) respondents had secondary education, about $31.7 \%$ possessed diploma qualification and $30.1 \%$ were degree holders. From these data, the researchers concluded that more than $60 \%$ of the respondents earned sufficient monthly incomes that allowed them to travel and have vacations (Refer to Table 1).

Table 1. Respondents profile $(\mathrm{n}=482)$

\begin{tabular}{llllll}
\hline & Frequency & Percent & & Frequency & Percent \\
\hline First visit & 187 & 38.8 & Malaysian & 426 & 88.4 \\
Repeat visit & 295 & 61.2 & Non-Malaysian & 56 & 11.6 \\
Malay & 340 & 70.5 & 20 years and below & 89 & 18.5 \\
Chinese & 35 & 7.3 & $21-29$ & 182 & 37.8 \\
Indian & 32 & 6.6 & $30-39$ & 109 & 22.6 \\
Others & 19 & 3.9 & $40-49$ & 67 & 13.9 \\
Non-Malaysian & 56 & 11.6 & $50-59$ & 29 & 6 \\
& & & $60-69$ & 6 & 1.2 \\
\hline Single & 244 & 50.6 & Primary & 3 & 0.6 \\
Married & 228 & 47.3 & Secondary & 132 & 27.4 \\
Divorced & 6 & 1.2 & Diploma & 153 & 31.7 \\
Widowed & 1 & 0.2 & Bachelor & 145 & 30.1 \\
Separated & 3 & 0.6 & Master & 44 & 9.1 \\
& & & PhD & 5 & 1.0 \\
\hline
\end{tabular}

\subsection{Factor Analysis and Alpha Scores}

The results of exploratory factor analysis (EFA) identifed the eigenvalue, KMO and Barlett's Test score. The varimax rotation method was performed and the number of factors was determined based on the eigenvalue criterion $(\lambda>1)$. Barlett's Test of Sphercity was statistically significant $(9097.469, \mathrm{p}=0.000)$ and the Kaiser-Meyer-Olkin (KMO) value was 0.938. Factor loadings for all items are shown in Table 2.

Out of 33 items, the principal component analysis revealed the presence of 7 factors with eigenvalues exceeding 1, explaining 65.96 per cent of the total variance, which exceeds the $60 \%$ threshold used in social sciences (Hair et al., 1995). Factor 1 clearly represents tourist satisfaction (criterion variable) that comprises nine items, explaining 38.57 percent of the variance with eigenvalues of 12.73 . Factor 2 contributes 7.50 percent of the total variance with eigenvalues of 2.48 , known as destination image and consisting of 8 items (destination image $=6$ items and perceived quality $=2$ items). Meanwhile, Factor 3 is the perceived quality which comprises six out of seven items used to measure the variable. This factor explains the 5.05 percent of variance with eigenvalues of 1.67. Factor 4 represents perceived value and consists of four items (perceived value $=3$ items and costs and risks $=1$ item), explaining the 4.47 percent variance with eigenvalues of 1.48 . Factor 5 which contributes 3.81 percent of the total variance with eigenvalues of 1.26 is the tourist expectations and consists of four items (expectations $=3$ items and perceived quality $=1$ item). Factor 6 , the costs and risks, comprises three out of five items used to measure the variable, and explains the 3.50 percent of the variance with the eigenvalues of 1.15. Factor 7, identified as a new predictor known as social-security, and comprises of two items, explains 3.07 percent of the variance with eigenvalues of 1.01 . 
Table 2. Factor Analysis of the variables $(\mathrm{n}=482)$

\begin{tabular}{|c|c|c|c|}
\hline Factor & Eigenvalues & $\begin{array}{l}\text { Factor } \\
\text { Loading }\end{array}$ & $\begin{array}{l}\text { \% Variance } \\
\text { Explained }\end{array}$ \\
\hline Factor 1: Tourist Satisfaction $(\alpha=0.928)$ & 12.727 & & 38.567 \\
\hline I really enjoyed the visit to Langkawi. & & 0.704 & \\
\hline I am satisfied with my decision to visit Langkawi. & & 0.708 & \\
\hline I prefer this destination. & & 0.705 & \\
\hline I have positive feelings regarding Langkawi. & & 0.692 & \\
\hline This experience is exactly what I need. & & 0.780 & \\
\hline My choice to purchase this trip was a wise one. & & 0.749 & \\
\hline This was a pleasant visit. & & 0.742 & \\
\hline This visit was better than expected. & & 0.752 & \\
\hline I rate Langkawi as a better destination as compared to similar tourist destinations. & & 0.718 & \\
\hline Factor 2: Destination Image $(\alpha=0.877)$ & 2.476 & & 7.503 \\
\hline I perceive the quality of the tourist centers in Langkawi is .... & & 0.407 & \\
\hline I perceive the quality of the tourist guides in Langkawi is .... & & 0.464 & \\
\hline Attractions ( natural, man-made, artificial, purpose built, heritage, special events) & & 0.573 & \\
\hline $\begin{array}{l}\text { Accessibility (entire transportation system comprising of routes, terminals and } \\
\text { vehicles) }\end{array}$ & & 0.681 & \\
\hline Amenities (accommodation and catering facilities, retailing, other tourists service) & & 0.668 & \\
\hline $\begin{array}{l}\text { Activities and events (all activities available at the destination and what tourists will } \\
\text { do during the visits) }\end{array}$ & & 0.583 & \\
\hline $\begin{array}{l}\text { Ancillary services (services used by tourists such as banks, telecommunication, post, } \\
\text { newsagent, hospital, etc.) }\end{array}$ & & 0.739 & \\
\hline Available packages (pre-arranged packages by intermediaries and principals) & & 0.677 & \\
\hline Factor 3: Perceived Quality $(\alpha=0.851)$ & 1.665 & & 5.046 \\
\hline I perceive the quality of accommodation in Langkawi is .... & & 0.693 & \\
\hline I perceive the quality of food in Langkawi is .... & & 0.738 & \\
\hline I perceive the quality of transportation in Langkawi is .... & & 0.726 & \\
\hline I perceive the quality of the local environment Langkawi is.... & & 0.590 & \\
\hline I perceive the quality of the tourist centers in Langkawi is.... & & 0.469 & \\
\hline I perceived the quality of tourist guides is .... & & 0.516 & \\
\hline Factor 4: Perceived Value $(\alpha=0.844)$ & 1.475 & & 4.471 \\
\hline In terms of money, travelling to Langkawi is .... & & 0.718 & \\
\hline In terms of time, travelling to Langkawi is .... & & 0.819 & \\
\hline In terms of effort, travelling to Langkawi is .... & & 0.842 & \\
\hline I consider travelling to Langkawi is expensive. & & -0.497 & \\
\hline Factor 5: Tourist Expectations $(\alpha=0.820)$ & 1.257 & & 3.809 \\
\hline My overall expectation of quality is .... & & 0.718 & \\
\hline My expectation towards customization is .... & & 0.474 & \\
\hline My expectation toward reliability is .... & & 0.715 & \\
\hline I perceive the quality of the attractions (natural \& heritage) in Langkawi is .... & & 0.583 & \\
\hline Factor 6: Costs and risks $(\alpha=0.543)$ & 1.154 & & 3.497 \\
\hline I consider travelling to Langkawi is expensive. & & 0.527 & \\
\hline I have to spend more time to visit Langkawi. & & 0.703 & \\
\hline I have to put more effort to visit Langkawi. & & 0.781 & \\
\hline KMO $=0.938$ & \multicolumn{3}{|l|}{ Sig. $=0.000$} \\
\hline Barlett's Test $=9097.469$ & T. Variance $=$ & $6 \%$ & \\
\hline
\end{tabular}

Table 2 also presents the reliability and internal consistency of each factor. A cut-off point of 0.40 was used to include items in interpretation of a factor. According to Sekaran and Bougie (2013), the closer the Cronbach's alpha is to 1 , the higher its internal consistency reliability. The alpha values for the variables are as follows: $\mathrm{F} 1=$ Tourist Satisfaction $(\alpha=0.928), \mathrm{F} 2=$ Destination Image $(\alpha=0.877), \mathrm{F} 3=$ Perceived Quality $(\alpha=0.851), \mathrm{F} 4=$ Perceived Value $(\alpha=0.844)$, F5 $=$ Tourist Expectations $(\alpha=0.820)$, F6 $=$ Costs and risks $(\alpha=0.543)$, F7 $=$ Social-security $(\alpha=0.719)$. Except for F6 and F7, all constructs have alpha scores of above 0.80 , which indicate that the items used to measure the constructs are reliable and satisfactory (Sekaran \& Bougie, 2013; Nunnally \& Bernstein, 1994; Nunnally, 1987). 


\subsection{Hypotheses Testing}

To test the hypotheses, multiple regressions were run. When all six predictors were regressed with the criterion variable, which is tourist satisfaction, the model was found to be fit (Refer to Table 3). The overall strength of the relationship is strong and acceptable $(\mathrm{R}=0.69)$. The percentage variance of satisfaction is explained by $47.5 \%$ of the variance of tourist expectations, perceived quality, perceived value, destination image, costs and risks, and social-security. Although the $\mathrm{R}^{2}$ value is below 0.50 , the F-value is significant at 0.00 and the model is fit. As such, there are other variables that may influence tourist satisfaction with Langkawi.

Table 3 shows that all predictors have positive relationships with tourist satisfaction; however, only four variables predict tourist satisfaction significantly. Tourist expectations $(B=0.237 ; \beta=0.216 ; p=0.000)$, destination image $(B=0.267 ; \beta=0.234 ; p=0.000)$, costs and risks $(B=0.126 ; \beta=0.141 ; p=0.000)$, and social-security $(B=0.183 ; \beta=0.199 ; p=0.000)$ emerge as important predictors of tourist satisfaction. These results support the findings of other researchers (Song et al., 2012; Lee et al., 2011; Xia et al., 2009; Chi \& Qu, 2008). However, perceived quality $(B=0.101 ; \beta=0.095 ; p=0.098)$ and perceived value $(B=0.027 ; \beta=0.023$; $\mathrm{p}=0.610)$ are insignificant to tourist satisfaction. These contradict the findings of earlier studies by Chen \& Chen (2010) and Quintal \& Polczynski (2010). Thus, H1, H4, and H5 are supported while H2 and H3 are rejected. The new predictor (social-security) was found to influence satisfaction significantly. This result gives support to Tasci \& Boylu (2010) research finding. In fact, out of the six predictors, social-security prevails as the most important predictor of satisfaction $(\mathrm{t}=5.245)$, while the second and third most important predictors are tourist expectations $(\mathrm{t}=4.423)$ and destination image $(\mathrm{t}=4.151)$.

These findings suggest that although visitors enjoy indulging in social activities and interacting with others during the trip, they also want the assurance that their safety is guaranteed. Furthermore, the tourists have realistic expectations that the trip would be enjoyable and worthwhile. These expectations have to be met in order for them to reflect on their Langkawi trip with great contentment.

Table 3. Regression analysis results $(\mathrm{n}=482)$

\begin{tabular}{lllll}
\hline & B & $\boldsymbol{\beta}$ & t-value & p-value \\
\hline Constant & 0.375 & & 2.019 & 0.037 \\
Tourist expectation & 0.237 & 0.216 & 4.423 & 0.000 \\
Perceived quality & 0.101 & 0.095 & 1.658 & 0.098 \\
Perceived value & 0.027 & 0.023 & 0.511 & 0.610 \\
Destination image & 0.267 & 0.234 & 4.151 & 0.000 \\
Costs and risks & 0.126 & 0.141 & 3.532 & 0.000 \\
Social-security & 0.183 & 0.199 & 5.245 & 0.000 \\
\hline $\mathrm{R}$ & 0.689 & & & \\
$\mathrm{R}^{2}$ & 0.475 & & & \\
F-value & 1.581 & & & \\
F-sig & 0.000 & & &
\end{tabular}

Note. Significant at the 0.05 level.

\section{Discussion}

From the $\mathrm{R}$-value, all factors predict tourists' satisfaction strongly $(\mathrm{R}=0.689)$. However, there are other factors that may affect tourists' satisfaction $\left(\mathrm{R}^{2}=0.475\right)$. Only four antecedents have significant positive relationships with satisfaction. High levels of expectations result in the higher overall satisfaction achieved. Likewise, the more positive the destination images are, the higher the satisfaction levels experienced by the visitors. This means that the destination service providers must strive to maintain the good image of their attractions because higher levels of customer satisfaction could lead to higher levels of retention and loyalty. Also, visitors who feel secure while travelling and those who are able to socialize with others achieve a higher level of satisfaction. Since safety is of great concern for most holidaymakers, the absence of tangible improvements in this aspect could eventually erode their personal attachment to the destination. In short, the possibility of harm or injury, no matter how slight, must be completely eliminated and improving the security aspects of the attractions and public facilities on the island should be a top priority of the tourism managers and policymakers.

The positive relationship between the costs and risks variable and satisfaction is unexpected. Numerous studies have indicated a negative relationship between the two variables, suggesting that the higher the costs and risks are, the lower the satisfaction (Yuksel \& Yuksel, 2007; Fornell et al., 2006; Monroe, 1990; Zeithaml, 1988). In 
this study, however, the visitors indicated that their satisfaction level remained high despite the increase in costs and risks. This could be due to the probability that the tourists were willing and prepared to absorb any increase in costs, and experiencing risky events such as riots, tsunami, earthquake or the SARS epidemic while vacationing on the island was perceived as remote possibilities.

\section{Conclusions and Recommendations}

The current research results give support to three hypotheses developed by the researchers. It is hoped that the results derived from the model will serve as the basis for the business development of Langkawi as a popular tourist destination in Malaysia. Understanding tourist expectations will provide meaningful clues on developing the tourist destination further and offering better goods and services. The findings of the study indicate that tourists are generally satisfied with their visits to the island. The overall image of Langkawi as a tourist destination is positive. Langkawi is perceived as offering good natural scenic beauty, reliable transportation and accommodation facilities and other travelling services, and as a consequence, many tourists profess their intention of revisiting Langkawi in the future. Hence, the researchers propose that Langkawi be positioned as a travel destination that promises good natural attractions, amenities, accessibility, activities, ancillary services, and available packages so as to support the Visit Malaysia Year 2016 and other future tourism campaigns.

Even though tourist satisfaction is high, tourist satisfaction monitoring should be performed on a continuous basis. The results may serve as valuable input for a trend analysis on the one hand and strategic discussions on the other. The goals are:

i) to identify strategic objectives at the destination level;

ii) to prepare tactical and operational plans (carefully balancing risk/cost and quality elements);

iii) to increase the competitiveness of a given destination;

iv) to allocate resources efficiently and effectively; and

v) to define future missions.

To increase satisfaction further, the researchers suggest that LADA and the tourism operators control the price of products and services on the island so that costs will not increase tremendously. They are encouraged to design packages that offer value-for-money tours to attract those from the lower income group to visit Langkawi. It would be timely and appropriate to revive the mid-nineties tourism campaign when Malaysia introduced "A Shopping Paradise' slogan to position itself as a value-for-money destination (Badaruddin, 2009). Other than that, tourism operators in the island should continue to upgrade the accommodation and surrounding environment because some respondents had suggested that more public amenities such as washrooms, cheaper accomodations, and bigger or clearer signage should be made available in the future. In addition, initiatives should be taken to identify the social and financial aspects to better understand the reasons why Langkawi remains a popular choice for vacation travel or why many continue to return for subsequent visits.

\section{Limitations and Future Research}

As a cross-sectional study, this research has some limitations since the data gathered make inferences about the population of interest at a defined time only. As such, a longitudinal research should be carried out to measure change across time and the direction of causality among relationships. Furthermore, the majority of the respondents were Malaysian citizens. Thus, future research should enlarge the sample and balance the number of local and foreigners, so that a comparative study between the two groups can be carried out. Moreover, only five antecedents of satisfaction were examined. Other determining factors related to travel ability should be included such as distance, place attachment, personal involvement and specific novelty. Also, an attempt to identify the risk-seeking and risk-avoiding groups of tourists should be undertaken. It would help tourism marketers design specific campaigns targeting those segments. Finally, it would be beneficial to conduct in-depth research to differentiate the level of satisfaction, loyalty and complaint among first-time and repeat visitors.

\section{Acknowledments}

This article is based on a research funded by the Langkawi Development Authority (LADA) under the LADA Grant 2012. The authors gratefully acknowledge the opportunity given by LADA to conduct an academic research on the visitors to Langkawi Island. 


\section{References}

Akama, J. S., \& Kieti, D. M. (2003). Measuring tourist satisfaction with Kenya's Wildlife Safari: A case study of Tsavo West National Park. International Journal of Tourism Management, 24(1), $73-81$. http://dx.doi.org/10.1016/S0261-5177(02)00044-4

Aqueveque, C. (2006). Extrinsic cues and perceived risks: The influence of consumption satisfaction. Journal of Consumer Marketing, 23(5), 237-247. http://dx.doi.org/10.1108/07363760610681646

Badaruddin, M. (2009). Image of Malaysia as a destination-A review. Retrieved from http://wwwhbp.usm.my/tourism/Papers/paper_image.htm

Baker, D. A., \& Crompton, J. L. (2000). Quality, satisfaction and behavioral intentions. Annals of Tourism Research, 27(3), 785-804. http://dx.doi.org/10.1016/S0160-7383(99)00108-5

Bigne, J., Sanchez, M., \& Sanchez, J. (2001). Tourism image, evaluation variables and after-purchase behavior: Interrelationships. Tourism Management, 22(6), 607-616. http://dx.doi.org/10.1016/S0261-5177(01)00035-8

Bolton, R. N., \& Drew, J. H. (1991). A longitudinal analysis of the impact of service changes on customer attitudes. Journal of Marketing, 55(1), 1-9. http://dx.doi.org/10.2307/1252199

Buhalis, D. (2000). Marketing competitive destinations of the future. Tourism Management, 21(1), 97-116. http://dx.doi.org/10.1016/S0261-5177(99)00095-3

Chanin, Y. (2011). The investigation of destination choice, satisfaction and loyalty intentions of international tourist. Proceedings of the 2011 Barcelona European Academic Conference, Barcelona Spain, pp. 277-284.

Chen, C. F. (2008). Investigating structural relationships between service quality, perceived value, satisfaction, and behavioral intentions for air passengers: Evidence from Taiwan. Transportation Research Part A, 42(4), 709-717. http://dx.doi.org/10.1016/j.tra.2008.01.007

Chen, C. F., \& Tsai, D. (2007). How destination image and evaluative factors affect behavioral intentions. Tourism Management, 28, 1115-1122. http://dx.doi.org/10.1016/j.tourman.2006.07.007

Chen, C., \& Chen, F. (2010). Experience quality, perceived value, satisfaction and behavioral intentions for heritage tourists. Tourism Management, 31, 29-35. http://dx.doi.org/10.1016/j.tourman.2009.02.008

Chen, J. S., \& Hsu, C. H. C. (2000). Measurement of Korean tourists' perceived images of overseas destinations. Journal of Travel Research, 38(4), 411-416. http://dx.doi.org/10.1177/004728750003800410

Chen, P. J., \& Kerstetter, D. I. (1999). International students' image of rural Pennsylvania as a travel destination. Journal of Travel Research, 37(3), 256-266. http://dx.doi.org/10.1177/004728759903700307

Chen, Y., Zhang, H., \& Qiu, L. (2013). A Review on Tourist Satisfaction of Tourism Destinations. Proceedings of 2nd International Conference on Logistics, Informatics and Service Science, pp. 593-604. http://dx.doi.org/10.1007/978-3-642-32054-5_83

Chi, C. G. Q., \& Qu, H. (2008). Examining the structural relationships of destination image, tourist satisfaction and destination loyalty: An integrated approach. Tourism Management, 29(4), 624-636. http://dx.doi.org/10.1016/j.tourman.2007.06.007

Choi, T. Y., \& Chu, R. (2001). Determinants of hotel guests' satisfaction and repeat patronage in the Hong Kong hotel industry. Hospitality Management, 20(3), 277-297. http://dx.doi.org/10.1016/S0278-4319(01)00006-8

Choi, W. M., Chan, A., \& Wu, J. (1999). A qualitative and quantitative assessment of Hong Kong's image as a tourist destination. Tourism Management, $20(3), \quad 361-365$. http://dx.doi.org/10.1016/S0261-5177(98)00116-2

Court, B., \& Lupton, R. A. (1997). Customer portfolio development: Modeling destination adapters, inactives, and rejecters. Journal of Travel Research, 36(1), 35-43. http://dx.doi.org/10.1177/004728759703600106

Cronin, J. J., Brady, M. K., \& Hult, G. T. M. (2000). Assessing the effects of quality, value and customer satisfaction on consumer behavioral intention in service environments. Journal of Retailing, 76(2), $193-218$. http://dx.doi.org/10.1016/S0022-4359(00)00028-2

Cronin, J., \& Taylor, S. (1992). Measuring service quality: A re-examination and extension. Journal of Marketing, 56(2), 55-68. http://dx.doi.org/10.2307/1252296

Darnell, A. C., \& Johnson, P. S. (2001). Repeat visits to attractions: A preliminary economic analysis. Tourism Management, 22(2), 119-126. 
de Rojas, C., \& Camarero, C. (2008). Visitors' experience, mood and satisfaction in a heritage context: Evidence from an interpretation center. Tourism Management, 29(3), 525-537. http://dx.doi.org/10.1016/j.tourman.2007.06.004

del Bosque, I. R., Martin, H. S., \& Collado, J. (2006). The role of expectations in consumer satisfaction formulation process: Empirical evidence in the travel agency sector. International Journal of Tourism Management, 27(3), 410-419. http://dx.doi.org/10.1016/j.tourman.2004.10.006

Dmitrovic, T., Cvelbar, L. K., Kolar, T., Brencic, M. M., Ograjeniaek, I., \& Vesna (2009). Conceptualizing tourist satisfaction at the destination level. International Journal of Culture, Tourism and Hospitality Research, 3(2), 116-126. http://dx.doi.org/10.1108/17506180910962122

Echtner, C. M., \& Ritchie, J. B. R. (1991). The meaning and measurement of destination image. Journal of Tourism Studies, 2(2), 2-12.

Eklof, J., \& Westlund, A. H. (2002). The European customer satisfaction index: Its background and the role of private concerns and public utilities. In G. Fabris \& S. Rolanda (Eds.), La Customer Satisfaction Nel Settore Pubblico. Milano: Franco Angeli Publishers.

English Historic Towns Forum. (1992). Townscape in trouble: Conservation areas-The case of change. English Historic Towns Forum, Bath.

Fornell, C., Johnson, M. D., \& Anderson, E. W. (1996). The American customer satisfaction index: Description, findings, and implications. Journal of Marketing, 60(4), 7-18. http://dx.doi.org/10.2307/1251898

Fuchs, M., \& Weiermair, K. (2003). New perspectives of satisfaction research in tourism destinations. Tourism Review, 58(3), 6-14. http://dx.doi.org/10.1108/eb058411

Gartner, W. C. (1994). Image Formation process. Journal of Travel \& Tourism Marketing, 2(2-3), 191-216. http://dx.doi.org/10.1300/J073v02n02_12

Goodrich, J. N. (1978). The relationship between preferences for and perceptions of vacation destinations: Application of a choice model. Journal of Travel Research, 17(2), 8-13. http://dx.doi.org/10.1177/004728757801700202

Grace, D., \& O'cass, A. (2005). Examining the effect of service brand communications on brand evaluation. Journal of Product and Brand Management, 14(2), 106-116. http://dx.doi.org/10.1108/10610420510592581

Hair, J. F., Anderson, R. E., Tatham, R. L., \& Black, W. C. (1995). Multivariate Data Analysis: With Readings. Upper Saddle River, NJ: Prentice Hall.

Haung, F., \& Su, L. (2010). A Study on the relationships of service fairness, quality, value, satisfaction, and loyalty among rural tourists. Paper presented at the 7th International Conference on Service Systems and Service Management, Tokyo. http://dx.doi.org/10.1109/icsssm.2010.5530137

Heung, V. C. S., \& Qu, H. (2000). Hong Kong as a travel destination: An analysis of Japanese tourists' satisfaction levels, and likelihood of them recommending Hong Kong to others. Journal of Travel and Tourism Marketing, 9(1-2), 57-80. http://dx.doi.org/10.1300/J073v09n01_04

Howat, G., \& Murray, D. (2002). The relationships among service quality, value, satisfaction, and future intentions of customers at an Australian sports and leisure centre. Sport Management Review, 5(1), 25-43. http://dx.doi.org/10.1016/S1441-3523(02)70060-0

Hui, T., Wan, D., \& Ho, A. (2007). Tourists' satisfaction, recommendation and revisiting Singapore. Tourism Management, 28(4), 965-975. http://dx.doi.org/10.1016/j.tourman.2006.08.008

Hunt, J. D. (1975). Image as a factor in tourist development. Journal of Travel Research, 13(3), 1-7. http://dx.doi.org/10.1177/004728757501300301

Joppe, M. D., Martin, W., \& Waalen, J. (2001). Toronto's image as a destination: A comparative importance-satisfaction analysis by origin of visitors. Journal of Travel Research, 39(3), 252-260. http://dx.doi.org/10.1177/004728750103900302

Kozak, M., \& Rimmington, M. (2000). Tourist satisfaction with Mallorca, Spain, as an off-season holiday destination. Journal of Travel Research, 38(3), 260-269. http://dx.doi.org/10.1177/004728750003800308

Kozak, M., Crotts, J., \& Law, R. (2007). The Impact of the perception of risk on international travelers. International Journal of Tourism Research, 9(4), 233-242. http://dx.doi.org/10.1002/jtr.607 
Lan, L., \& Tse, E. (1998). Antecedents and consequences of expatriate satisfaction in the Asian Pacific. Tourism Management, 19(2), 135-143. http://dx.doi.org/10.1016/S0261-5177(97)00105-2

Lather, A. S., Singh, R., \& Singh, K .A. (2012). Comparing the levels of expectation and satisfaction of Indian and foreign adventure tourists visiting India. Applied Studies in Agribusiness and Commerce, 6(3-4), 5-14. Budapest: Agroinform Publishing House.

Lee, C. K., Yoon, Y. S., \& Lee, S. K. (2007). Investigating the relationships among perceived value, satisfaction, and recommendations: The case of the Korean DMZ. Tourist Management, 28(1), 204-214. http://dx.doi.org/10.1016/j.tourman.2005.12.017

Lee, C., Lee, Y., \& Lee, B. (2005). Korea's destination image formed by the 2002 World Cup. Annals of Tourism Research, 32(4), 839-858. http://dx.doi.org/10.1016/j.annals.2004.11.006

Lee, S., Jeon, S., \& Kim, D. (2011). The impact of tour quality and tourist satisfaction on tourist loyalty: The case of Chinese tourists in Korea. Tourism Management, 32(5), 1115-1124. http://dx.doi.org/10.1016/j.tourman.2010.09.016

Lembaga Pembangunan Langkawi. (2014). Laman Web Rasmi LADA. Retrieved from http://www.lada.gov.my/v2/

Leong, Q. L., Muhd. Shahrim, A. K., \& Mohhidin, O. (2010). Relationships between Malaysian food image, tourist satisfaction and behavioural intention. World Applied Sciences Journal, 10(Special issue of Tourism \& Hospitality), 164-171.

Lin, C. H., Morais, D. B., Kerstetter, D. L., \& Hou, J. S. (2007). Examining the role of cognitive and affective image in predicting choice across natural, developed, and theme-park destinations. Journal of Travel Research, 46(2), 183-194. http://dx.doi.org/10.1177/0047287506304049

Lovelock, C. H. (2000). Service Marketing. NJ: Prentice Hall.

Millan, A., \& Esteban, A. (2004). Development of a Multiple-item Scale for Measuring Customer Satisfaction in Travel Agencies Services. Tourism Management, 25(5), 533-546. http://dx.doi.org/10.1016/j.tourman.2003.07.002

Mohamad, M., Abdullah, A. R., \& Mokhlis, S. (2012). Tourists' evaluation of destination image and future behavioural intention: The case of Malaysia. Journal of Management and Sustainability, 2(1), 181-189. http://dx.doi.org/10.5539/jms.v2n1p181

Mohamad, M., Ali, A. M., \& Ab Ghani, N. I. (2011). A structural model of destination image, tourists' satisfaction and destination loyalty. International Journal of Business and Management Studies, 3(2), 167-177.

Monroe, A. K. (1990). Pricing: Making Profitable Decisions. NY: McGraw-Hill.

Ngobo, P. V. (1997). The standards issue: An accessibility-diagnosticity perspective. Journal of Consumer Satisfaction, Dissatisfaction and Complaining Behavior, 10, 61-79.

Nikorn, Y., \& Ampasri, P. (2012). The antecedent and consequences of tourist satisfaction: An empirical study of tourists in Sirinhorn Museum Thailand. In Local community: The foundation of development in the ASEAN Economic Community (AEC). Proceedings of the 2012 International and National Conference for the Sustainable Community Development, Thailand, February 16-19, 3-9 .

Nunnally, J. C. (1978). Psychometric Theory. New York: McGraw-Hill.

Nunnally, J. C., \& Bernstein, I. H. (1994). Psychometric Theory. Sydney: McGraw Hill.

Oliver, R. L. (1980). A cognitive model of the antecedents and consequences of satisfaction decision. Journal of Marketing Research, 17(4), 460-469. http://dx.doi.org/10.2307/3150499

Oliver, R. L. (1994). Conceptual issues in the structural analysis of consumption emotion, satisfaction, and quality: Evidence in a service setting. In C. T. Allen \& D. R. John (Eds.), Advances in Consumer Research (vol. 21, pp. 16-22). Provo, UT: Association for Consumer Research.

Oliver, R. L. (1997). Satisfaction: A Behavioral Perspective on the Consumer. New York: McGraw-Hill.

Oliver, R. L., \& Swan, J. E. (1989). Consumer perceptions on interpersonal equity and satisfaction in transactions: A field survey approach. Journal of Marketing, 53(2), 21-35. http://dx.doi.org/10.2307/1251411 
Performance Management Delivery Unit. (2012). NKEA: Tourism. Retrieved from etp.pemandu.gov.my/annual report/

Petrick, J. F., \& Backman, S. J. (2002). An examination of the construct of perceived value for the prediction of golf travelers' intentions to revisit. Journal of Travel Research, 41(1), 38-45.

Pisnik, K. A., \& Snoj, B. (2007). Direct and indirect effects of perceived price and perceived value of the mobile phone. Annals of Telecommunications, 62(9/10), 913-935.

Prayag, G. (2009). Tourists' evaluation of destination image, satisfaction and future behavioral intentions: The case of Mauritius. Journal of Travel \& Tourism Marketing, 26(8), 836-853. http://dx.doi.org/10.1080/10548400903358729

Prayag, G., \& Ryan, C. (2011). Antecedents of tourists' loyalty to Mauritius: The role and influence of destination image, place attachment, personal involvement, and satisfaction. Journal of Travel Research, 51(3), 342-356. http://dx.doi.org/10.1177/0047287511410321

Quintal, V. A., \& Polczynski, A. (2010). Factors influencing tourists' revisit intentions. Asia Pacific. Journal of Marketing and Logistics, 22(4), 554-578. http://dx.doi.org/10.1108/13555851011090565

Reisinger, Y., \& Turner, L. W. (2003). Cross-cultural Behavior in Tourism: Concepts and Analysis. Oxford: Butterworth-Heinemann.

Roscoe, J. T. (1975). Fundamental Research Statistics for the Behavioral Sciences. New York: Holt, Rinehart and Winston.

Ross, G. F. (1993). Destination evaluation and vacation preferences. Annals of Tourism Research, 2(3), 477-489. http://dx.doi.org/10.1016/0160-7383(93)90004-M

Ruiz, D. M., \& Gremler, D. D. (2008). Service value revisited: Specifying a higher-order, formative measure. Journal of Business Research, 61(12), 1278-1291. http://dx.doi.org/10.1016/j.jbusres.2008.01.015

Rust, R. T., \& Oliver, R. L. (1994). Service quality: Insights and managerial implications from the frontier. In R. T. Rust \& R. L. Oliver (Eds), Service Quality: New Directions in Theory and Practice (pp. 1-19). Thousand Oaks, CA: Sage Publications. http://dx.doi.org/10.4135/9781452229102.n1

Rust, R., Danaher, P., \& Varki, S. (1999). Comparative service quality and business outcomes. Working paper, Center for Service Marketing, Vanderbilt University, Nashville.

Sadeh, E., Asgari, F., Mousavi, L., \& Sadeh, S. (2012). Factors affecting tourist satisfaction and its consequences. Journal of Basic and Applied Scientific Research, 2(2), 1557-2012.

Saleh, F., \& Ryan, C. (1993). Conviviality-A source of satisfaction for hotel guest? An application of the SERVQUAL model. In P. Johnson \& B. Thomas (Eds.), Choice and Demand in Tourism (pp. 107-122). London: Biddles Ltd. Guildford and King's Lynn.

Schroeder, T. (1996). The relationship of residents' image of their state as a tourist destination and their support for tourism. Journal of Travel Research, 34(4), 71-73. http://dx.doi.org/10.1177/004728759603400411

Sekaran, U., \& Bougie, R. (2013). Research Methods for Business: A Skill Building Approach. West Sussex: John Wiley \& Sons, Ltd.

Severt, D., Wong, Y., Chen, P., \& Breiter, D. (2007). Examining the motivation, perceived performance and behavioral intentions of convention attendees: Evidence from a regional conference. Tourism Management, 28(2), 399-408. http://dx.doi.org/10.1016/j.tourman.2006.04.003

Song, H., Van de Veen, R., Li, G., \& Chen, J. (2012). The Hong Kong tourist satisfaction index. Annals of Tourism Research, 39(1), 459-479. http://dx.doi.org/10.1016/j.annals.2011.06.001

Spreng, R. A., \& Mackoy, R. D. (1996). An empirical examination of a model of perceived service quality and satisfaction. Journal of Retailing, 72(2), 201-214. http://dx.doi.org/10.1016/S0022-4359(96)90014-7

Tasci, A. D. A., \& Gartner, W. C. (2007). Destination image and its functional relationships. Journal of Travel Research, 45(4), 413-425. http://dx.doi.org/10.1177/0047287507299569

Tasci, A. D. A., Gartner, W. C., \& Cavusgil, S. T. (2007). Conceptualization and operationalization of destination image. Journal of Hospitality \& Tourism Research, 31(2), 194-223. http://dx.doi.org/10.1177/1096348006297290

Tasci, A. D., \& Boylu, Y. (2010). Cultural comparison of tourists' safety perception in relation to trip satisfaction. 
International Journal of Tourism Research, 12(2), 179-192.

Taylor, S. A., \& Baker, T. L. (1994). An Assessment of the relationship between service quality and consumer satisfaction in the formation of consumer's purchase intentions. Journal of Retailing, 70(2), 163-178. http://dx.doi.org/10.1016/0022-4359(94)90013-2

Tian-Cole, J., Crompton, L., \& Willson, V. L. (2002). An empirical investigation of the relationships between service quality, satisfaction and behavioral intentions among visitors to a wilflife refuge. Journal of Leisure Research, 34(1), 1-24.

Um, S., Chon, K., \& Ro, Y. (2006). Antecedents of revisit intentions. Annals of tourism Research, 33(4), 1141-1158. http://dx.doi.org/10.1016/j.annals.2006.06.003

Vavra, T. G. (1997). Improving Your Measurement of Customer Satisfaction. ASQ, Milwaukee, WI: Quality Press.

World Tourism Organization (WTO). (1995). Tourism market trends: World 1985-1994. WTO, Madrid.

World Travel and Tourism Council (2013). Economic Impact Research 2013. Retrieved from http://www.wttc.org/

Wu, H. L., Liu, C. H., \& Hsu, W. H. (2008). An integrative model of customers' perceptions of health care services in Taiwan. The Service Industries Journal, 28(9), 1307-1319. http://dx.doi.org/10.1080/02642060802230130

Xia, W., Jie, Z., Chaolin, G., \& Feng, Z. (2009). Examining antecedents and consequences of tourist satisfaction: A structural modelling approach. Tsinghua Science and Technology, 14(3), 397-406. http://dx.doi.org/10.1016/S1007-0214(09)70057-4

Yuksel, A., \& Yuksel, F. (2007). Shopping risk perceptions: Effects on tourists' emotions, satisfaction and expressed loyalty intentions. Tourism $\quad$ Management, $28(3), 713$. http://dx.doi.org/10.1016/j.tourman.2006.04.025

Zabkar, V., Brencic, M., \& Dmitrovic, T. (2010). Modelling perceived quality, visitor satisfaction and behavioural intentions at the destination level. Tourism Management, 31(4), 537-546. http://dx.doi.org/10.1016/j.tourman.2009.06.005

Zeithaml, V. A. (1998). Consumer perception of price, quality and value: A means-end model and synthesis of evidence. Journal of Marketing, 52(3), 2-22. http://dx.doi.org/10.2307/1251446

\section{Appendix A}

Pilot test Results-Mean Score and Cronbach's Alpha $(n=50)$

\begin{tabular}{lll}
\hline Variables & Mean & Cronbach's alpha \\
\hline Tourists' satisfaction & & 0.884 \\
TS1 & 4.680 & \\
TS2 & 4.600 & \\
TS3 & 4.580 & \\
TS4 & 4.500 & \\
TS5 & 4.460 & \\
TS6 & 4.620 & \\
TS7 & 4.500 & \\
TS8 & 4.380 & \\
TS9 & 4.640 & \\
Tourists' expectation & & 0.723 \\
TE1 & 4.540 & \\
TE2 & 4.460 & \\
TE3 & 4.660 & \\
Perceived quality & & 0.712 \\
PQ1 & 4.540 & \\
PQ2 & 4.580 & \\
PQ3 & 4.460 & \\
PQ4 & 4.340 & \\
PQ5 & 4.640 & \\
PQ6 & 4.500 & \\
PQ7 & 4.480 & \\
\hline
\end{tabular}




\begin{tabular}{lll}
\hline Perceived value & & 0.738 \\
PV1 & 4.160 & \\
PV2 & 4.280 & \\
PV3 & 4.320 & \\
Destination image & & 0.724 \\
DI1 & 4.560 & \\
DI2 & 4.360 & \\
DI3 & 4.460 & \\
DI4 & 4.580 & \\
DI5 & 4.440 & \\
DI6 & 4.180 & \\
Costs and risks & & 0.550 \\
CR1 & 2.400 & \\
CR2 & 4.120 & \\
CR2 & 4.060 & \\
CR4 & 4.460 & \\
CR5 & 4.380 & \\
\hline
\end{tabular}

\section{Copyrights}

Copyright for this article is retained by the author(s), with first publication rights granted to the journal.

This is an open-access article distributed under the terms and conditions of the Creative Commons Attribution license (http://creativecommons.org/licenses/by/3.0/). 